Article

\title{
Field Investigation on River Hydrochemical Characteristics and Larval and Juvenile Fish in the Source Region of the Yangtze River
}

\author{
Liangyuan Zhao ${ }^{1,2, *, \dagger}$, Wei Li ${ }^{1,2, \dagger}$, Li Lin ${ }^{1,2}$, Weijie Guo ${ }^{1,2}$, Weihua Zhao ${ }^{1,2}$, \\ Xianqiang Tang ${ }^{1,2}, *$, Dandan Gong ${ }^{1,2}$, Qingyun $\mathrm{Li}^{1,2}$ and Ping $\mathrm{Xu}^{2}$ \\ 1 Basin Water Environmental Research Department, Changjiang River Scientific Research Institute, \\ Wuhan 430010, China \\ 2 Hubei Provincial Key Laboratory of River Basin Water Resources and Eco-environmental Sciences, \\ Changjiang River Scientific Research Institute, Wuhan 430010, China \\ * Correspondence: zhaoliangyuannew@163.com (L.Z.); ckyshj@126.com (X.T.); \\ Tel.: +86-27-8292-7263 (L.Z.); +86-27-8292-6192 (X.T.) \\ + The first two authors contributed equally to this work.
}

Received: 22 April 2019; Accepted: 24 June 2019; Published: 28 June 2019

\begin{abstract}
The source region of the Yangtze River (SRYR) is located in the Qinghai-Tibet Plateau, where the climatic conditions and alpine-cold natural conditions are harsh. Field investigations of the hydrochemical characteristics and larva and juvenile fish in rivers of the SRYR were carried out in July 2018 with the aim of obtaining further information on the unique ecological environment status of this plateau area. The results of the present research indicated that majority of the river water quality parameters in the SRYR were in the range of class I to class II, according to the classification of the environmental quality standard for surface water (GB3838-2002) in China. Among 12 kinds of metal ions, the concentrations of four major ions occurred in the following order: $\mathrm{Ca}>\mathrm{Na}>\mathrm{Mg}$ $>\mathrm{K}$. The concentrations of eight heavy metal ions ( $\mathrm{Fe}, \mathrm{Mn}, \mathrm{Cu}, \mathrm{Zn}, \mathrm{Pb}, \mathrm{Cd}, \mathrm{Cr}$ and $\mathrm{As}$ ) were all within the class I water range based on GB3838-2002. A total of three species of larval and juvenile fish, i.e., Triplophysa stenura (T. stenura), Schizopygopsis microcephalus Herzenstein (S. microcephalus) and Triplophysa bleekeri (T. bleekeri), were collected from 11 sampling sites. It was found that T. stenura covered the widest distribution range and was the most abundant. The results of principal component analysis and canonical correspondence analysis demonstrated that the distribution of S. microcephalus exhibited a positive response to water temperature, a positive response to $\mathrm{K}$ and a negative correlation with water temperature were demonstrated in the distribution of T. stenura. T. bleekeri distribution had a positive response to $\mathrm{Cu}$, but negative responses to total phosphorus and total dissolved solid.
\end{abstract}

Keywords: ecological environment; larval and juvenile fish; water quality; the source region of the Yangtze River

\section{Introduction}

The Yangtze River (Changjiang) is the largest river in Asia and the third largest river in the world in terms of length $(6300 \mathrm{~km})$ and discharge $\left(900 \mathrm{~km}^{3} /\right.$ year $)$, which rises from the Qinghai-Tibetan Plateau in the west and crosses the China through 11 provinces [1,2]. The source region of the Yangtze River (SRYR) is located in the hinterland of the Qinghai-Tibet Plateau, which is called the roof of the world, is well known as the "water tower of China" [3-5]. The SRYR is located between $90^{\circ} 43^{\prime}-96^{\circ} 45^{\prime} \mathrm{E}$ and $32^{\circ} 30^{\prime}-35^{\circ} 35^{\prime} \mathrm{N}$, and has an average altitude of more than 4000 meters and an area of $12.24 \times 10^{4} \mathrm{~km}^{2}$; its area accounts for $43.6 \%$ of the total area of the Three-river Headwater Region, which is the source of the Yangtze, Yellow and Lancang Rivers in China and 8\% of the total area of the Yangtze River 
basin [3-5]. The SRYR is an important area in the Qinghai-Tibet Plateau; its main function is to ensure the long history of the Yangtze River and to transport water resources in high quality to the downstream [3,4]. The SRYR is mainly composed of the Dangqu, Tuotuo and Chumaer Rivers [3,5]. The SRYR plays an important role in regulating the water volume and climate in the downstream due to its important ecological functions, such as water resources conservation and regulation, biodiversity conservation and ensuring the eco-security of the Yangtze River basin, which occupies an important position in the role of ecological security in China and even in Southeast Asia [6,7].

In the past 50 years, the ecological environment in this source region has been deteriorating due to the influence of natural processes, the intensification of human activities and the impact of global climate change [4-6]. Environmental problems such as receding glaciers, shrinking wetlands, degradation of grasslands and worsening soil erosion have became increasingly prominent, which pose a huge threat to the water resources, ecological security and sustainable economic and social development for the whole Yangtze River basin [5-7]. Therefore, increasing attention has been paid to the SRYR in recent years, and the scientific research activities of this region are more frequent [6,7]. However, due to the special geographical and climatic conditions in Qinghai-Tibet Plateau, research regarding the aspect of aquatic ecological environment has been restricted in this region [8,9].

Many previous studies have focused on the major ion chemistry and hydrobiology in the middle stream and downstream of Yangtze River $[1,10,11]$. However, only a few studies on the hydrochemistry and hydroecology of the river have been conducted in the SRYR. The previous results of our research regarding the spatial-temporal distribution of water quality in the SRYR showed that the water quality of rivers in the SRYR is good, i.e., belonging to class I to class II of the classification of the environmental quality standards for surface water (GB3838-2002) in China in most regions. Influenced by the sediment contents of river water and regional geological conditions, water quality indexes varied among rivers in different regions in the SRYR, and water quality exhibited a small inter-year variation with a similar fluctuation [10]. Jiang et al. (2015) investigated the chemical composition of the high mountain-rivers in the SRYR; their results indicated that the main cations are $\mathrm{Na}^{+}, \mathrm{Ca}^{2+}, \mathrm{Mg}^{2+}$ and $\mathrm{K}^{+}$, while the main anions are $\mathrm{Cl}^{-}, \mathrm{HCO}_{3}{ }^{-}, \mathrm{SO}_{4}{ }^{2-}$ and $\mathrm{NO}_{3}{ }^{-}, \mathrm{Na}^{+}$and $\mathrm{Cl}^{-}$are the dominant ions in river water [11]. Aquatic organisms such as fish, macroinvertebrates, phytoplankton, etc. are important components of river water ecosystems in the SRYR. Yin et al. (2015) reported that diatoms were the main groups in 29 species of phytoplankton with abundances at each sampling site of $9.14-13.60 \times 10^{4} / \mathrm{L}$ [9]. Arthropods were the predominant groups for macroinvertebrates, comprising $86.2 \%$ of the total density and 95.8\% of the total biomass respectively in the rivers of the SRYR investigated by Pan et al. (2013) [12]. Nonetheless, scant information is available on the compositions and community diversity of fish in rivers of the SRYR. There have been three large-scale investigations of water ecological environment in the SRYR [13], and the investigation results indicated that the rivers in the SRYR were basically kept in the natural state. However, the background value of water chemistry indexes in some rivers was high due to the greater influence from the geological environment $[10,13]$.

With the intensification of climate change and anthropogenic activities, the ecological and environmental problems in the SRYR have attracted extensive attention [14,15]. It is of great significance for the protection of the SRYR to obtain basic data on the water ecological environment in this ecologically sensitive and fragile area. The few aforementioned studies have investigated and analyzed the hydrochemistry and aquatic organisms of the rivers in the SRYR and obtained valuable data; however, there are still insufficient data on the comprehensive water environment and aquatic biological characteristics in this area, especially regarding information on fish distribution and the relationship between fish characteristics and river hydrochemical signatures. Therefore, more research is required to elucidate the spatial patterns of the river hydrochemical characteristics and diversity of aquatic communities in the different rivers of the SRYR [10,12].

A scientific investigation was conducted in July 2018 by the Changjiang River Scientific Research Institute with the aim of obtaining more information on the unique ecological environment status in this plateau area by performing an analysis of the basic data of aquatic ecological environment. 
The present research analyzes variations in the characteristics of water quality parameters and larval and juvenile fish distribution characteristics in different river sections in the SRYR, and reveals the main environmental factors affecting larval and juvenile fish distribution, which is important to provide a scientific basis for the protection of the ecological environment of the SRYR.

\section{Materials and Methods}

\subsection{Sampling Site}

The river system in the SRYR has a fan-shaped distribution, and five major rivers, the Chumaer, Tuotuo, Dangqu, Gaerqu and Buqu Rivers, being distributed in this wide area $[11,16,17]$. Field investigations of water quality and larva and juvenile fish of rivers in the SRYR were carried out in July 2018. A total of 12 sampling sites in 6 rivers in the SRYR were investigated (Figure 1), i.e., the Tongtian, Dangqu, Tuotuo and Chumaer, Buqu and Gaerqu Rivers, with the latter two being the two main tributaries of the Dangqu; the detailed location of each sampling site is shown in Table 1.

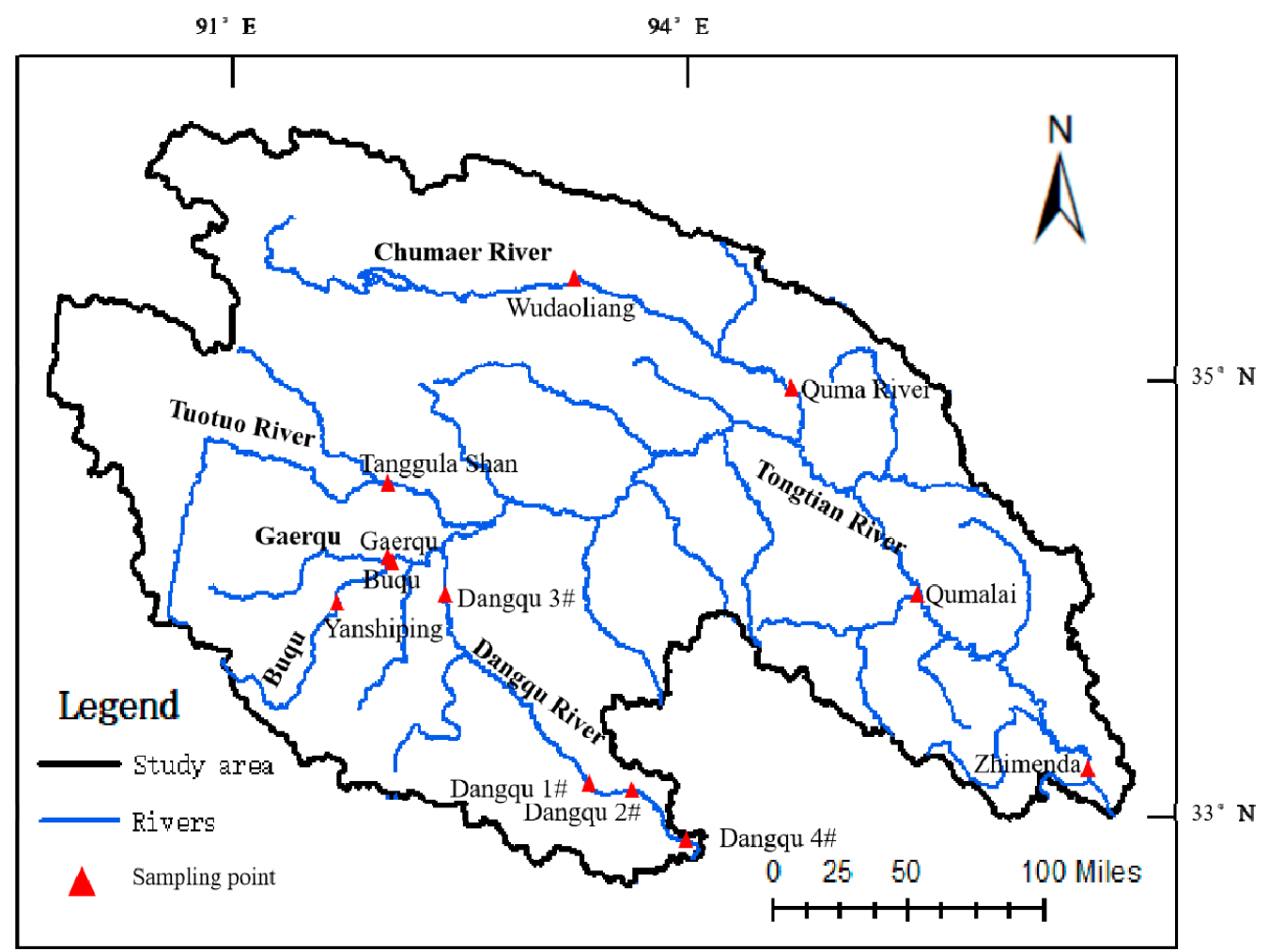

Figure 1. The schematic map in the study areas. 
Table 1. The geographic coordinate and altitude of sampling sites.

\begin{tabular}{ccccc}
\hline \multirow{2}{*}{ Sampling Site } & \multicolumn{2}{c}{ Geographic Coordinate } & \multirow{2}{*}{ Altitude(m) } \\
\hline \multirow{2}{*}{ River Name } & River Section & Longitude & Latitude & \\
\hline \multirow{2}{*}{ Tongtian River } & Zhimenda & $33^{\circ} 00^{\prime} 38^{\prime \prime} \mathrm{N}$ & $97^{\circ} 14^{\prime} 18^{\prime \prime} \mathrm{E}$ & 3489 \\
\cline { 2 - 4 } & Qumalai & $34^{\circ} 01^{\prime} 32^{\prime \prime} \mathrm{N}$ & $95^{\circ} 49^{\prime} 16^{\prime \prime} \mathrm{E}$ & 4019 \\
\cline { 2 - 4 } & Dangqu 4\# & $32^{\circ} 41^{\prime} 08^{\prime \prime} \mathrm{N}$ & $94^{\circ} 32^{\prime} 42^{\prime \prime} \mathrm{E}$ & 4861 \\
\cline { 2 - 4 } & Dangqu 2\# & $32^{\circ} 52^{\prime} 08^{\prime \prime} \mathrm{N}$ & $94^{\circ} 12^{\prime} 55^{\prime \prime} \mathrm{E}$ & 4656 \\
\cline { 2 - 4 } & Dangqu 1\# & $32^{\circ} 53^{\prime} 03^{\prime \prime} \mathrm{N}$ & $93^{\circ} 50^{\prime} 52^{\prime \prime} \mathrm{E}$ & 4701 \\
\cline { 2 - 4 } Gaerqu & Dangqu 3\# & $33^{\circ} 38^{\prime} 15^{\prime \prime} \mathrm{N}$ & $92^{\circ} 46^{\prime} 54^{\prime \prime} \mathrm{E}$ & 4514 \\
\hline \multirow{2}{*}{ Buqu } & Gaerqu & $33^{\circ} 51^{\prime} 57^{\prime \prime} \mathrm{N}$ & $92^{\circ} 22^{\prime} 01^{\prime \prime} \mathrm{E}$ & 4530 \\
\cline { 2 - 4 } & Buqu & $33^{\circ} 51^{\prime} 55^{\prime \prime} \mathrm{N}$ & $92^{\circ} 22^{\prime} 01^{\prime \prime} \mathrm{E}$ & 4530 \\
\hline Tuotuo River & Tanggula Shan & $34^{\circ} 13^{\prime} 15^{\prime \prime} \mathrm{N}$ & $92^{\circ} 26^{\prime} 37^{\prime \prime} \mathrm{E}$ & 4532 \\
\hline \multirow{2}{*}{ Chumaer river } & Wudaoliang & $35^{\circ} 18^{\prime} 23^{\prime \prime} \mathrm{N}$ & $93^{\circ} 18^{\prime} 15^{\prime \prime} \mathrm{E}$ & 4494 \\
\cline { 2 - 4 } & Quma River & $34^{\circ} 51^{\prime} 20^{\prime \prime} \mathrm{N}$ & $94^{\circ} 56^{\prime} 30^{\prime \prime} \mathrm{E}$ & 4221 \\
\hline
\end{tabular}

\subsection{Field Monitoring}

The following parameters of river water, including $\mathrm{pH}$, water temperature, dissolved oxygen (DO), conductivity, oxidation reduction potential (ORP), total dissolved solids (TDS), chlorophyll a, turbidity and salinity, were simultaneously measured in the field using a multiparameter water quality sonde (EXO2, YSI, USA).

\subsection{Sample Collection and Analysis}

Three replicates of river water samples in each sampling site were collected at a depth of $10 \mathrm{~cm}$ and stored in pre-cleaned polyethylene bottles free of air for laboratory analyses. Immediately after collection, water samples of $2 \mathrm{~L}$ were acidified with sulfuric acid to a $\mathrm{pH}<2$, which was used for the analysis of total phosphorus and total nitrogen. Water samples acidified with nitric acid were used for the analysis of metal ions, including $\mathrm{K}, \mathrm{Na}, \mathrm{Ca}, \mathrm{Mg}, \mathrm{Fe}, \mathrm{Mn}, \mathrm{Cu}, \mathrm{Zn}, \mathrm{Pb}, \mathrm{Cd}, \mathrm{Cr}$ and $\mathrm{As}$.

Metal ions, including $\mathrm{K}, \mathrm{Na}, \mathrm{Ca}$ and $\mathrm{Mg}$ were measured by Microwave Plasma-Atomic Emission Spectrometer (4200, Agilent, USA), and other metal ions were measured by inductively coupled plasma mass spectrometer (NexION 300x, PerkinElmer, USA). The recoveries of various metal ions in different river water samples ranged from 85.2 to $99.5 \%$ and with a detection limit of $0.01 \mu \mathrm{g} / \mathrm{L}$ to $0.82 \mu \mathrm{g} / \mathrm{L}$.

Chemical parameters including total nitrogen (TN), total phosphorus (TP), permanganate index $\left(\mathrm{COD}_{\mathrm{Mn}}\right)$, the degree of mineralization and total hardness of river samples were measured in the laboratory according to the standard method. TN was analyzed using the alkaline potassium persulfate digestion-UV spectrophotometric method. TP was analyzed using the ammonium molybdate method. $\mathrm{COD}_{\mathrm{Mn}}$ was measured by the acidic potassium permanganate titration method. The degree of mineralization and total hardness were measured by the methods of gravimetric method and EDTA titration method, respectively, according to the protocols described in Chinese Standard Methods [18,19].

\subsection{Larval and Juvenile Fish Collection and Analysis}

The larval and juvenile fish samples were collected with a 60 mesh hand-net along the river bank. The samples were stored in $95 \%$ ethanol. All fish samples were identified on the basis of "Fishes of Qinghai-Tibet Plateau" [20]. 


\subsection{Statistical Analysis}

Data were tested for normality (Levene's test) and homogeneity of variance (Kolmogorov-Smirnov test) prior to analysis and presented as mean. The significant differences among the multiple water quality parameters and fish quantities were analyzed by one-way analysis of variance (ANOVA) with Tukey's multiple comparison test. The differences between the two parameters or two sets of data were analyzed by independent samples $t$ test (two-tailed). Pearson correlations were performed to explore the relationship among the various water quality parameters and fish numbers. The above all statistical analyses were performed by using GraphPad Prism (ver.5.0, GraphPad Software, USA). Principal component analysis (PCA) and canonical correspondence analysis (CCA) were conducted by Canoco (ver.4.5, Microcomputer Power, USA) for comparing environmental variables at each sampling point and illustrating relations between fish assemblages and key environmental variables that have been described as important habitat components of larval and juvenile fish, respectively.

\section{Results}

\subsection{Water Quality}

\subsubsection{Field Monitoring Parameters}

Field monitoring parameters of water quality in different rivers in the SRYR are presented in Table 2. The $\mathrm{pH}$ values of river water samples in different ranged from 8.29 to 8.71 and conductivity ranged from 212.4 to $2874.5 \mu \mathrm{s} / \mathrm{cm}$ with an average of $918.37 \mu \mathrm{s} / \mathrm{cm}$, which indicating an alkaline river environment and may relate to the regional alkaline soil environment $[10,11]$. The water temperature of river water fluctuated significantly, ranging from $9.6^{\circ} \mathrm{C}$ and $19.46^{\circ} \mathrm{C}$. Compared with the research data from 2012, 2014 and 2015, water temperature of the same sampling site fluctuated greatly from year to year, mainly due to weather factors such as temperature, sunlight intensity and precipitation varied in different sampling time in the SRYR [10]. The conductivity of water samples ranged from $212.4-2874.5 \mu \mathrm{s} / \mathrm{cm}$, and the TDS ranges from 178 to $2468 \mathrm{mg} / \mathrm{L}$ with the average value of $747.05 \mathrm{mg} / \mathrm{L}$, which is more than 7 times on average than the world average of $100 \mathrm{mg} / \mathrm{L}[11,21]$ and closely related to the conductivity $(r=0.99, p<0.01)$, salinity $(r=1.00, p<0.01)$, degree of mineralization $(r=-0.99$, $p<0.01)$, total hardness $(r=0.93, p<0.01)$ and $\mathrm{Ca}(r=0.65, p<0.05)$ (Table A1). Based on sampling time, there was a certain difference in the TDS concentrations between 2018 and 2010 (457-5063 mg/L). This difference may due to the difference in sediment concentration and ion content caused by the difference of precipitation in different years [10].

From a spatial perspective, the conductivity and TDS content of Chumaer River were higher than that of other rivers in the SRYR $(p<0.01)$, which was mainly due to the difference of the sediment content in water and regional geological conditions. The salinity of different sampling sites ranged from 0.11-2.02 ppt, and the salinity of Chumaer River was higher than that of other rivers in the SRYR $(p<0.05)$, which was affected by the difference of geological conditions and regional climatic conditions. The chlorophyll a content in the main rivers of the SRYR is generally low, ranging from 0.24 to $3.37 \mathrm{mg} / \mathrm{L}$. Such low content of algae in river water may be caused by special environmental factors, such as low water temperature, high sediment concentration, high turbidity and low nutrient concentrations such as nitrogen and phosphorus, which are not conducive to algae growth, and in turn lead to lower levels of chlorophyll a in the river water [9]. The dissolved oxygen content (DO) of water ranged from $5.55-7.41 \mathrm{mg} / \mathrm{L}$, which was in the water quality range of class I-II based on the environmental quality standard for surface water (GB3838-2002) except for sites of Quma River. 
Table 2. Water quality parameters of different rivers by field monitoring in the SRYR.

\begin{tabular}{|c|c|c|c|c|c|c|c|c|c|c|}
\hline \multicolumn{2}{|c|}{ Sampling Site } & \multicolumn{9}{|c|}{ Field Monitoring Parameters } \\
\hline River Name & River Section & $\begin{array}{c}\text { Water } \\
\text { Temperature }\left({ }^{\circ} \mathrm{C}\right)\end{array}$ & $\begin{array}{l}\text { Conductivity } \\
(\mu \mathrm{S} / \mathrm{cm})\end{array}$ & $\begin{array}{c}\text { TDS } \\
(\mathrm{mg} / \mathrm{L})\end{array}$ & $\begin{array}{l}\text { Salinity } \\
\text { (ppt) }\end{array}$ & $\begin{array}{c}\mathrm{DO} \\
(\mathrm{mg} / \mathrm{L})\end{array}$ & $\mathrm{pH}$ & ORP & $\begin{array}{l}\text { Turbidity } \\
\text { (NTU) }\end{array}$ & $\begin{array}{c}\text { Chlorophyll a } \\
(\mu \mathrm{g} / \mathrm{L})\end{array}$ \\
\hline \multirow{2}{*}{ Tongtian River } & Zhimenda & 14.36 & 1154 & 942 & 0.73 & 7.04 & 8.48 & 241.3 & 442.14 & 1.1 \\
\hline & Qumalai & 18.29 & 1202.8 & 918 & 0.71 & 6.11 & 8.44 & 267.3 & 328.8 & 0.63 \\
\hline \multirow{4}{*}{ Dangqu River } & Dangqu 4\# & 13.56 & 215.2 & 178 & 0.13 & 7.13 & 8.57 & 236.2 & 1.59 & 0.38 \\
\hline & Dangqu 2\# & 15.79 & 366.2 & 288 & 0.21 & 6.22 & 8.56 & 233.5 & 1.49 & 0.79 \\
\hline & Dangqu 1\# & 15.42 & 212.4 & 184.6 & 0.11 & 7.41 & 8.51 & 179.4 & 15.4 & 0.24 \\
\hline & Dangqu 3\# & 15.85 & 412.9 & 325 & 0.24 & 6.55 & 8.45 & 252.2 & 142.58 & 0.58 \\
\hline Gaerqu & Gaerqu & 9.6 & 233.3 & 215 & 0.16 & 6.75 & 8.54 & 208.7 & 624.9 & 1.18 \\
\hline \multirow{2}{*}{ Buqu River } & Buqu & 9.82 & 259.9 & 239 & 0.18 & 6.71 & 8.54 & 222.9 & 389.5 & 0.63 \\
\hline & Yanshiping & 11.73 & 224.2 & 196 & 0.14 & 6.25 & 8.46 & 228.9 & 112.8 & 1.74 \\
\hline Tuotuo River & Tanggula Shan & 10.223 & 1263 & 1127 & 0.88 & 6.45 & 8.71 & 198.8 & 4350.9 & 3.37 \\
\hline \multirow{2}{*}{ Chumaer River } & Wudaoliang & 12.27 & 2874.5 & 2468 & 2.02 & 6.39 & 8.63 & 174.9 & 962.8 & 1.74 \\
\hline & Quma River & 19.46 & 2602 & 1884 & 1.51 & 5.55 & 8.54 & 243.9 & 375.56 & 0.8 \\
\hline
\end{tabular}




\subsection{2. $\mathrm{TN}, \mathrm{TP}$ and $\mathrm{COD}_{\mathrm{Mn}}$}

The concentrations of nitrogen, phosphorus and other nutrients in water are important indicators of eutrophication, which can reflect the status of water pollution and eutrophication process [22]. The concentrations of TN and TP in river water at each sampling site in the SRYR are displayed in Figures 2 and 3, respectively. As can be seen in Figure 2, except for the sampling sites of Dangqu 4\# and Tanggula Shan, there was no significant difference in TN among other sampling sites, and the concentrations were below the detectable limit, which indicated that TN concentrations of river waters in the SRYR were in the range of class I, according to GB3838-2002. The TN concentrations of Dangqu 4\# and Tanggula Shan were relatively higher $(p<0.05)$, i.e., in the range of class I-II $(0.2-0.5 \mathrm{mg} / \mathrm{L})$. The concentrations of TP at the majority of the sampling sites were in the range of class I-II $(0.02-0.1 \mathrm{mg} / \mathrm{L})$ based on GB3838-2002, while river of Buqu had the highest concentrations of TP $(p<0.01)$, i.e., in the range of class II-III $(>0.1 \mathrm{mg} / \mathrm{L})$. In general, the concentrations of nitrogen and phosphorus in the river waters of the SRYR were at relatively low levels, and the TN concentration in the sections of the Chumaer and Zhimenda Rivers in 2015 were lower than the detection limit [10]. Annual variations of nitrogen and phosphorus were not obvious when compared with the data in 2012 and 2015, which indicated that although the status of surface water quality in the SRYR is greatly affected by the natural environment, due to low population density, low pollutant discharge and large environment capacity, the water body possess a strong self-purification capacity and the water quality remains relatively stable [10].

The $C O D_{M n}$ of river water in each sampling site in the SRYR is shown in Figure 4. $C O D_{M n}$ is one of the important indicators used to evaluate the pollution level of the water [23] and the $\mathrm{COD}_{\mathrm{Mn}}$ concentrations of water samples in 12 sampling sites in the SRYR ranged from $0.96-5.64 \mathrm{mg} / \mathrm{L}$, and were in the range of class I ( $\leq 2 \mathrm{mg} / \mathrm{L})$ and class I-II (2-4 mg/L) according to (GB 3838-2002) (Figure 4), while at the Dangqu 4\# and Dangqu 2\# sites, the $\mathrm{COD}_{\mathrm{Mn}}$ concentrations were in the range of class II-III (4-6 mg/L).

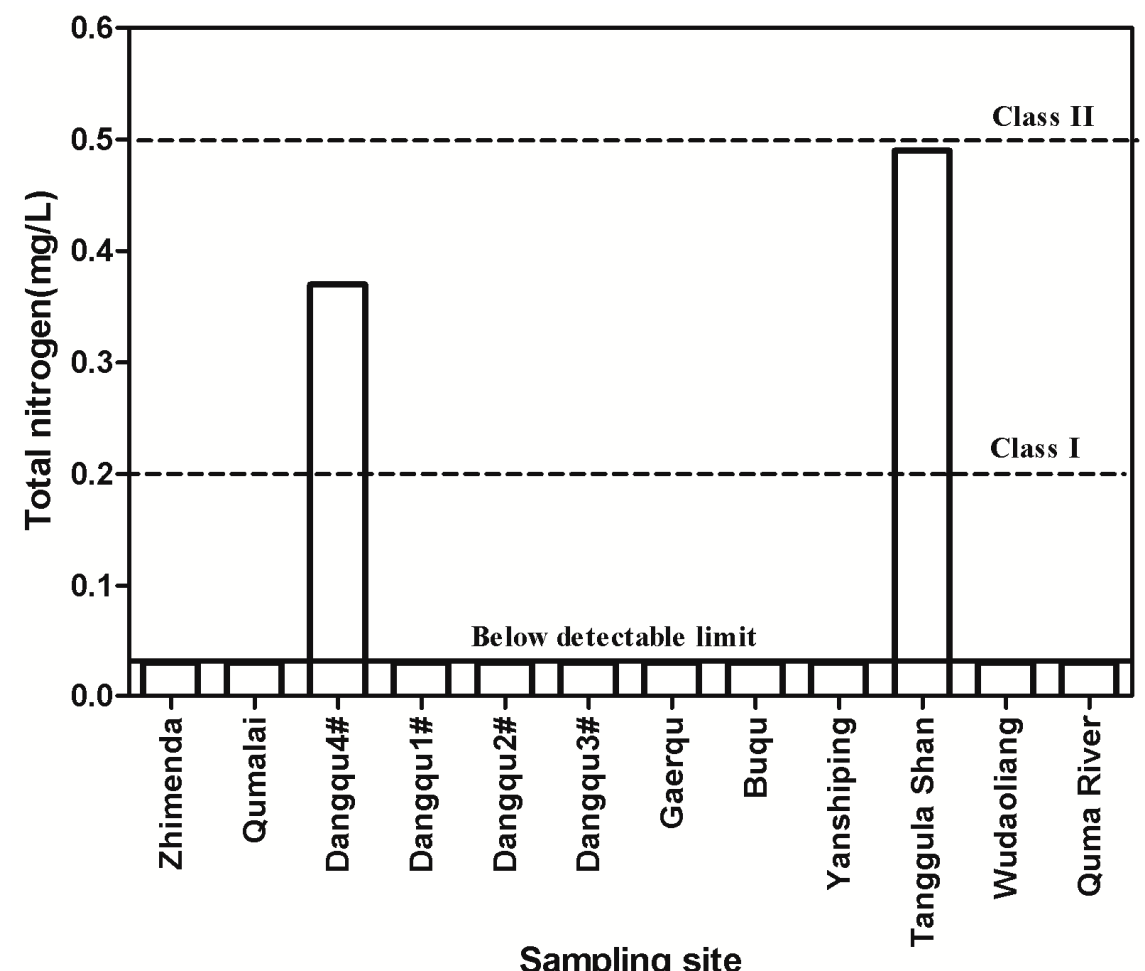

Figure 2. The concentration of total nitrogen in river water of each sampling site in the SRYR. 


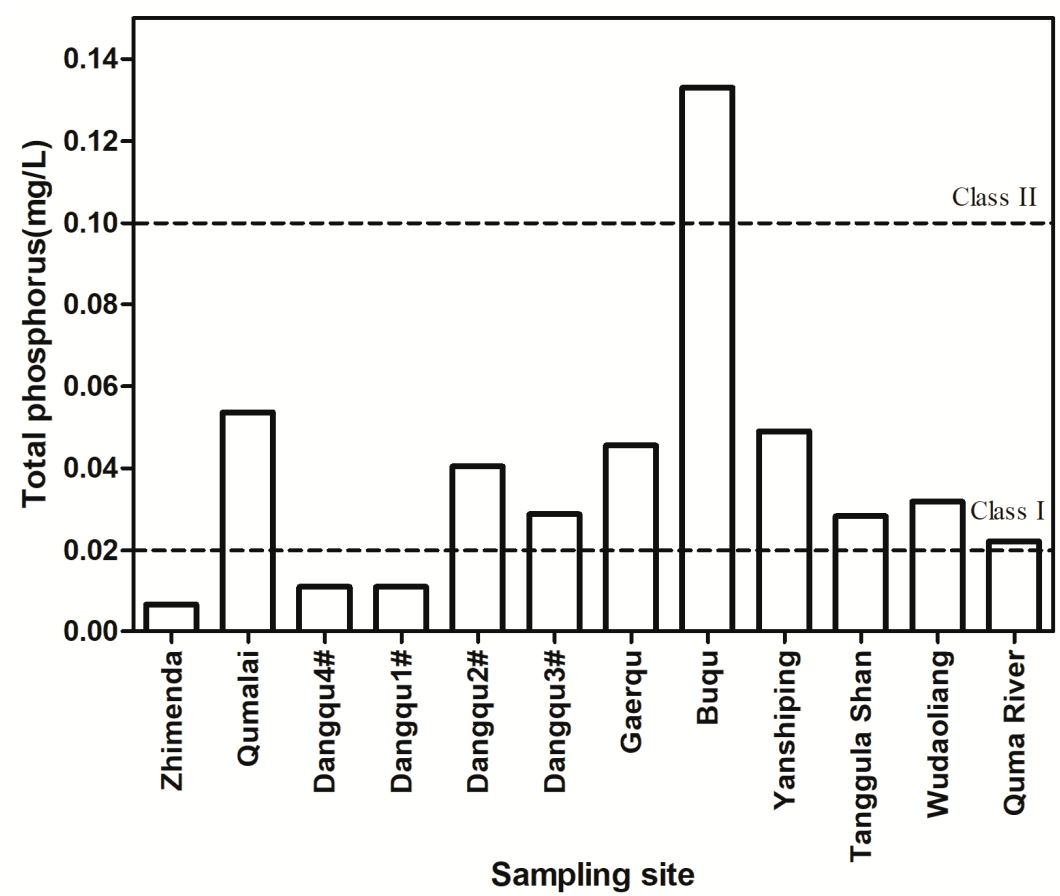

Figure 3. The concentration of total phosphorus in river water of each sampling site in the SRYR.

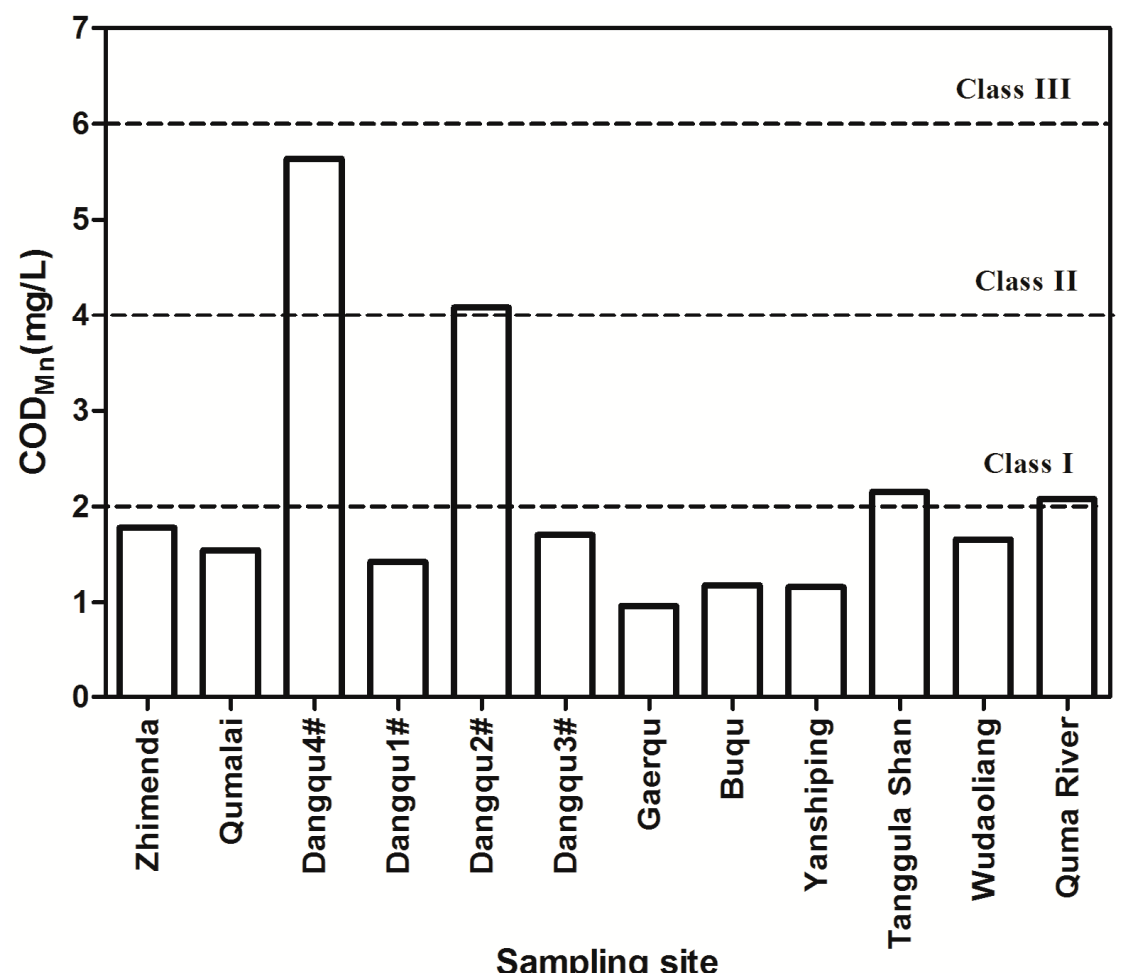

Figure 4. Permanganate index of river water in each sampling site in the SRYR.

\subsubsection{The Degree of Mineralization and Total Hardness}

The degree of mineralization and total hardness of river water in each sampling site in the SRYR are shown in Figure 5. The total hardness of river water is mainly formed by the dissolution of carbonates and bicarbonates containing calcium and magnesium in water, followed by the dissolution of sulfates, chlorides and other minerals [24]. The total hardness of the sampling sites in the SRYR ranged from $138.66-433.02 \mathrm{mg} / \mathrm{L}$. The degree of mineralization and total hardness of river waters 
in SRYR showed high levels of consistency in terms of concentrations; both in the Chumaer River were significantly higher than those in the Tuotuo and Dangqu Rivers, which was consistent with the variation of conductivity and total dissolved solids. Correlation analysis demonstrates that the degree of mineralization is significantly related to total hardness $(r=0.95, p<0.01)$, and that Ca had a positive relationship with the degree of mineralization $(r=0.69, p<0.01)$ and total hardness $(r=0.63, p<0.05$, Table A1). This phenomenon was mainly caused by differences in the geological conditions in the SRYR.
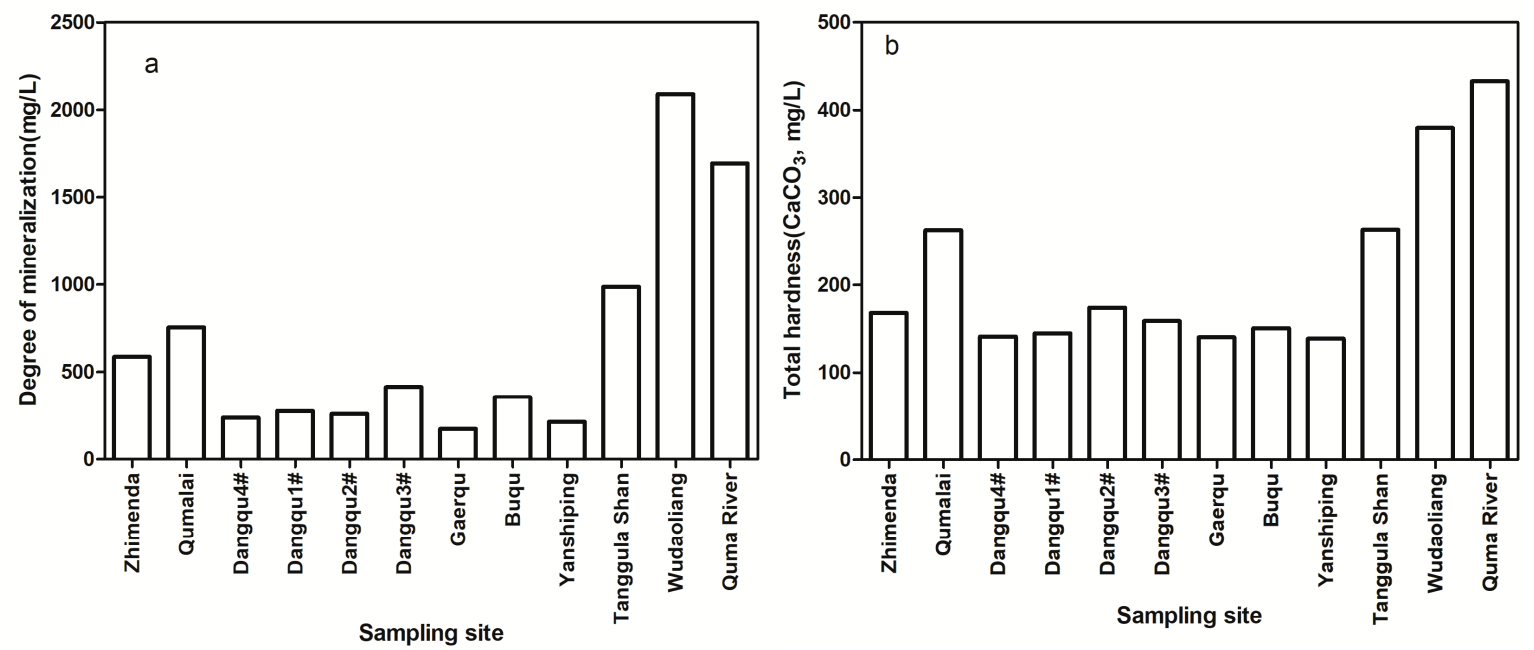

Figure 5. The degree of mineralization (a) and total hardness (b) of river water in each sampling site in the SRYR.

\subsubsection{Metal Ions}

Water quality is affected by various natural and human factors. The composition of main ions in water is widely used to identify the basic processes which control the chemical composition of water, such as rock weathering, evaporation crystallization of water, and the input of atmospheric precipitation material $[5,11,25]$. The concentrations of 12 kinds of metal ions in the river waters in the SRYR are listed in Table 3. The concentrations of four major elements follows the order of $\mathrm{Ca}>\mathrm{Na}>$ $\mathrm{Mg}>\mathrm{K}$, which is similar to the major element distribution of river waters in the three river source region [25]. Since $\mathrm{Na}^{+}$and $\mathrm{K}^{+}$are mainly derived from the weathering of evaporates and silicates, while $\mathrm{Ca}^{2+}$ and $\mathrm{Mg}^{2+}$ from carbonates, evaporites and silicates [26,27], the $\left(\mathrm{Ca}^{2+}+\mathrm{Mg}^{2+}\right) /\left(\mathrm{Na}^{+}+\right.$ $\mathrm{K}^{+}$) ratio can be used to evaluate the relative contribution of different rocks. In the present research, the average $\left(\mathrm{Ca}^{2+}+\mathrm{Mg}^{2+}\right) /\left(\mathrm{Na}^{+}+\mathrm{K}^{+}\right)$ratio of river waters in the SRYR is approximately 4.4 , which is more than the averaged $\left(\mathrm{Ca}^{2+}+\mathrm{Mg}^{2+}\right) /\left(\mathrm{Na}^{+}+\mathrm{K}^{+}\right)$ratio of the global rivers (2.2), This suggests again that the chemistry of the river waters in the SRYR is strongly influenced by carbonate weathering $[11,28]$. The concentrations of the eight heavy metal elements ( $\mathrm{Fe}, \mathrm{Mn}, \mathrm{Cu}, \mathrm{Zn}, \mathrm{Pb}, \mathrm{Cd}, \mathrm{Cr}$ and $\mathrm{As}$ ) were all within the class I range based on GB3838-2002.

In the present research, the concentrations of the same metal ion were found to be significantly different in the different sampling sites in the SRYR, with variations of several or even dozens of times, which may indicate that the characteristics of hydrochemistry are closely related to the geomorphic type, rock properties and weathering degree of the study area $[5,27]$. In addition, due to physical weathering in the SRYR, a large number of fine particles of mineral rocks, instantaneous hydrological factors, as well as the high concentrations of suspended matter, will make the concentration of elements vary greatly. Compared with the reported metal ion concentrations of river water in the SRYR, the metal concentrations in the SRYR were found to be lower than the reported values in 1998, and were basically consistent with the literature reported in 2012 [13,29]. Among the four major metals of $\mathrm{K}, \mathrm{Na}, \mathrm{Ca}$ and $\mathrm{Mg}$, the Na concentration is much lower than the reported values in the SRYR, which may be related to the regional differences in the geological background of the source area. 
Table 3. The concentrations of metal ions in river waters of the SRYR

\begin{tabular}{|c|c|c|c|c|c|c|c|c|c|c|c|c|c|}
\hline \multicolumn{2}{|c|}{ Sampling Site } & \multicolumn{12}{|c|}{ Metal Ions } \\
\hline River Name & River Section & $\begin{array}{c}\mathrm{K} \\
(\mathrm{mg} / \mathrm{L})\end{array}$ & $\underset{(\mathrm{mg} / \mathrm{L})}{\mathrm{Na}}$ & $\begin{array}{c}\mathrm{Ca} \\
(\mathrm{mg} / \mathrm{L})\end{array}$ & $\underset{(\mathrm{mg} / \mathrm{L})}{\mathrm{Mg}}$ & $\begin{array}{c}\text { Fe } \\
(\mu \mathrm{g} / \mathrm{L})\end{array}$ & $\begin{array}{c}\mathrm{Mn} \\
(\mu \mathrm{g} / \mathrm{L})\end{array}$ & $\begin{array}{c}\mathrm{Cu} \\
(\mu \mathrm{g} / \mathrm{L})\end{array}$ & $\begin{array}{c}\mathrm{Pb} \\
(\mu \mathrm{g} / \mathrm{L})\end{array}$ & $\begin{array}{c}\mathrm{Zn} \\
(\mu \mathrm{g} / \mathrm{L})\end{array}$ & $\begin{array}{c}\mathrm{Cd} \\
(\mu \mathrm{g} / \mathrm{L})\end{array}$ & $\begin{array}{c}\mathrm{Cr} \\
(\mu \mathrm{g} / \mathrm{L})\end{array}$ & $\begin{array}{c}\text { As } \\
(\mu \mathrm{g} / \mathrm{L})\end{array}$ \\
\hline \multirow{2}{*}{ Tongtian River } & Zhimenda & 1.88 & 4.94 & 37.80 & 6.17 & 2.36 & 4.00 & 0.43 & $<0.09$ & $<0.67$ & $<0.05$ & 0.24 & 1.73 \\
\hline & Qumalai & 2.77 & 9.01 & 77.46 & 11.87 & 3.99 & 2.96 & 0.59 & $<0.09$ & $<0.67$ & $<0.05$ & 0.53 & 3.24 \\
\hline \multirow{4}{*}{ Dangqu River } & Dangqu 4\# & 1.64 & 26.57 & 53.53 & 10.31 & 11.19 & 1.05 & 2.27 & $<0.09$ & 0.94 & $<0.05$ & 0.57 & 0.79 \\
\hline & Dangqu 1\# & 3.03 & 9.95 & 39.50 & 19.24 & 3.22 & 3.02 & 2.25 & $<0.09$ & 7.56 & $<0.05$ & 0.23 & 3.20 \\
\hline & Dangqu 2\# & 1.38 & 11.10 & 51.18 & 8.39 & 3.38 & 3.95 & 1.35 & $<0.09$ & 1.34 & $<0.05$ & 0.27 & 2.54 \\
\hline & Dangqu 3\# & 2.87 & 25.58 & 64.19 & 12.12 & 2.93 & 0.67 & 0.66 & $<0.09$ & $<0.67$ & $<0.05$ & 0.22 & 2.74 \\
\hline Gaerqu & Gaerqu & 5.98 & 3.75 & 41.78 & 22.11 & 2.10 & 0.64 & 0.51 & $<0.09$ & 1.68 & $<0.05$ & 0.28 & 1.60 \\
\hline \multirow{2}{*}{ Buqu River } & Buqu & 1.03 & 7.64 & 57.74 & 1.54 & 2.51 & 6.49 & 0.45 & $<0.09$ & 0.76 & $<0.05$ & 0.31 & 1.67 \\
\hline & Yanshiping & 6.29 & 3.87 & 40.19 & 25.14 & 2.85 & 0.58 & 0.64 & $<0.09$ & 0.98 & $<0.05$ & 0.29 & 2.97 \\
\hline Tuotuo River & Tanggula Shan & 2.56 & 46.56 & 34.99 & 12.23 & 1.41 & 0.74 & 0.59 & $<0.09$ & 1.61 & $<0.05$ & 0.25 & 5.30 \\
\hline \multirow{2}{*}{ Chumaer River } & Wudaoliang & 2.95 & 2.94 & 105.1 & 14.78 & 5.38 & 2.27 & 0.96 & $<0.09$ & $<0.67$ & $<0.05$ & 0.34 & 1.44 \\
\hline & Quma River & 1.40 & 2.23 & 65.04 & 14.53 & 3.32 & 0.25 & 0.50 & $<0.09$ & 2.25 & $<0.05$ & 0.37 & 0.72 \\
\hline
\end{tabular}




\subsection{Fish Distribution Characteristics}

\subsubsection{The Quantity and Distribution of Fish}

The distribution and quantities of fish are shown in Figure 6. Three species of fish were found at the 11 sampling sites. Among the three species, Triplophysa stenura (T. stenura) had the highest occurrence rate, $91 \%$, which was observed at all the sampling sites except for Dangqu 4. Schizopygopsis microcephalus Steindachner (S. microcephalus) was 64\%, and Triplophysa bleekeri (T. bleekeri) had the lowest occurrence rate, i.e., $27 \%$. The quantity of $T$. stenura was the highest, i.e., $77.8 \%$ of the total quantity. S. microcephalus was $18.5 \%$. The quantity of $T$. bleekeri was the lowest, i.e., $3.7 \%$ of total quantity. Correlation analysis for fish numbers and environmental factors demonstrates that the larval and juvenile fish number has a positive relationship with $\mathrm{pH}(r=0.57, p<0.05)$ and turbidity $(r=0.68$, $p<0.01)$ and a negative relationship with water temperature $(r=-0.64, p<0.05)$ and ORP $(r=-0.69$, $p<0.01$ ) (Table A1).

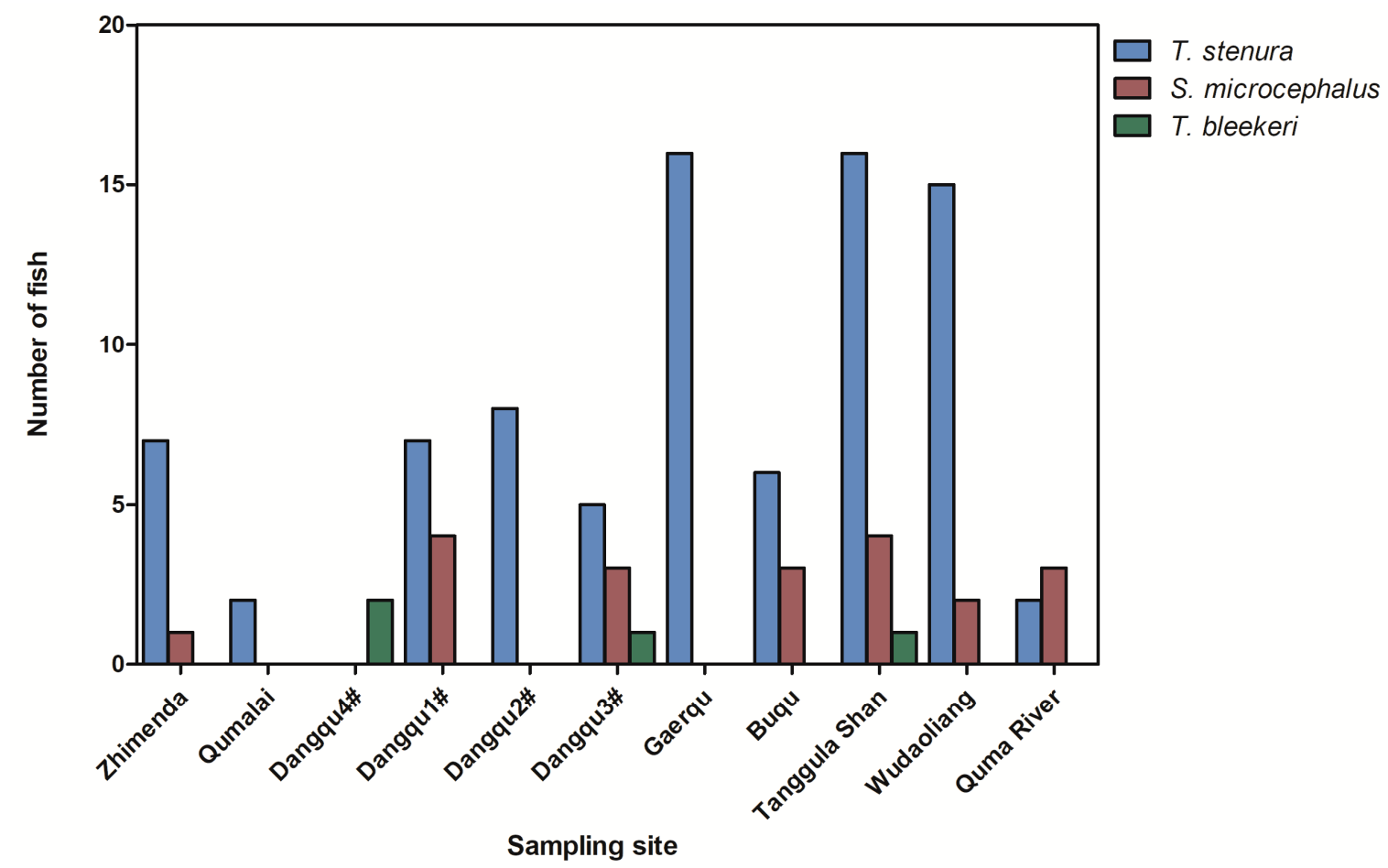

Figure 6. The quantity and distribution of larval and juvenile fish in each sampling site.

\subsubsection{The Relationship between Fish Distribution and Environment Factors}

Water quality parameters are important factors affecting the distribution of fish in river water [30]. Salinity is one of the key water quality factors affecting the distribution of fish in the Gulf [31]. Nutrients such as total phosphorus are positively correlated with fish distribution $(>10 \mathrm{~cm})$ in lakes [32]. Climate change is a global issue that is of great concern to the international community [33]. The Qinghai-Tibet Plateau is the "starting zone" for China's global change, and it is also a sensitive area for global climate change and one of the regions with the greatest warming [34,35]. From 1977 to 2015, with the increase of temperature, the water temperature of the Tuotuo River in the SRYR increased by $1.6^{\circ} \mathrm{C}$ and $1.7^{\circ} \mathrm{C}$ in June and July, respectively [36]. Due to the simple and fragile structure of the plateau water ecosystem, plateau fish are more susceptible to climate change [37]. At present, there are few basic data on the water quality survey of the SRYR under warm and humid climatic conditions, and the relationship between river fish distribution and water quality in the SRYR has not yet been established. Therefore, it is necessary to establish the relationship between water quality parameters such as nutrient salt, 
water temperature and heavy metals and fish distribution, and to provide a scientific basis for carrying out water ecological protection and restoration work in the SRYR.

Principal component analysis (PCA) was performed on 22 water quality parameters, including water temperature, conductivity, TDS, salinity, dissolved oxygen, $\mathrm{pH}$, ORP, turbidity, $\mathrm{K}, \mathrm{Na}, \mathrm{Ca}, \mathrm{Mg}$, $\mathrm{Fe}$, $\mathrm{Mn}, \mathrm{Cu}, \mathrm{Zn}, \mathrm{Cr}$, As, total phosphorus, $\mathrm{COD}_{\mathrm{Mn}}$, the degree of mineralization and total hardness (Figure 7). Canonical correspondence analysis (CCA) was performed on the selected environmental factors and fish characteristics to identify key water quality factors affecting the distribution characteristics of larval and juvenile fish (Figure 8). The results indicated that the first and second axes of PCA accounted for $64.06 \%$ and $15.75 \%$ of differences, respectively. The first major components mainly explain the environmental factors: $\mathrm{Cu}$, turbidity and TDS, which mainly represent the transparency characteristics of river waters. The second major components mainly explain the TP, $\mathrm{K}, \mathrm{DO}, \mathrm{T}$ and $\mathrm{Ca}$, mainly representing nutrients and physical factors of river water quality.

The eight environmental driving factors in the PCA results were analyzed by CCA with various fish numbers at each sample. The results of the analysis are shown in Figure 8. The first and second axes explained $34.78 \%$ and $20.53 \%$ of the species differences, respectively. The distribution of S. microcephalus had a positive response to water temperature, while the distribution of $T$. stenura had a positive response to $\mathrm{K}$ and a negative correlation with water temperature. The distribution of $T$. bleekeri showed a positive response to $\mathrm{Cu}$, but a negative response to TP and TDS.

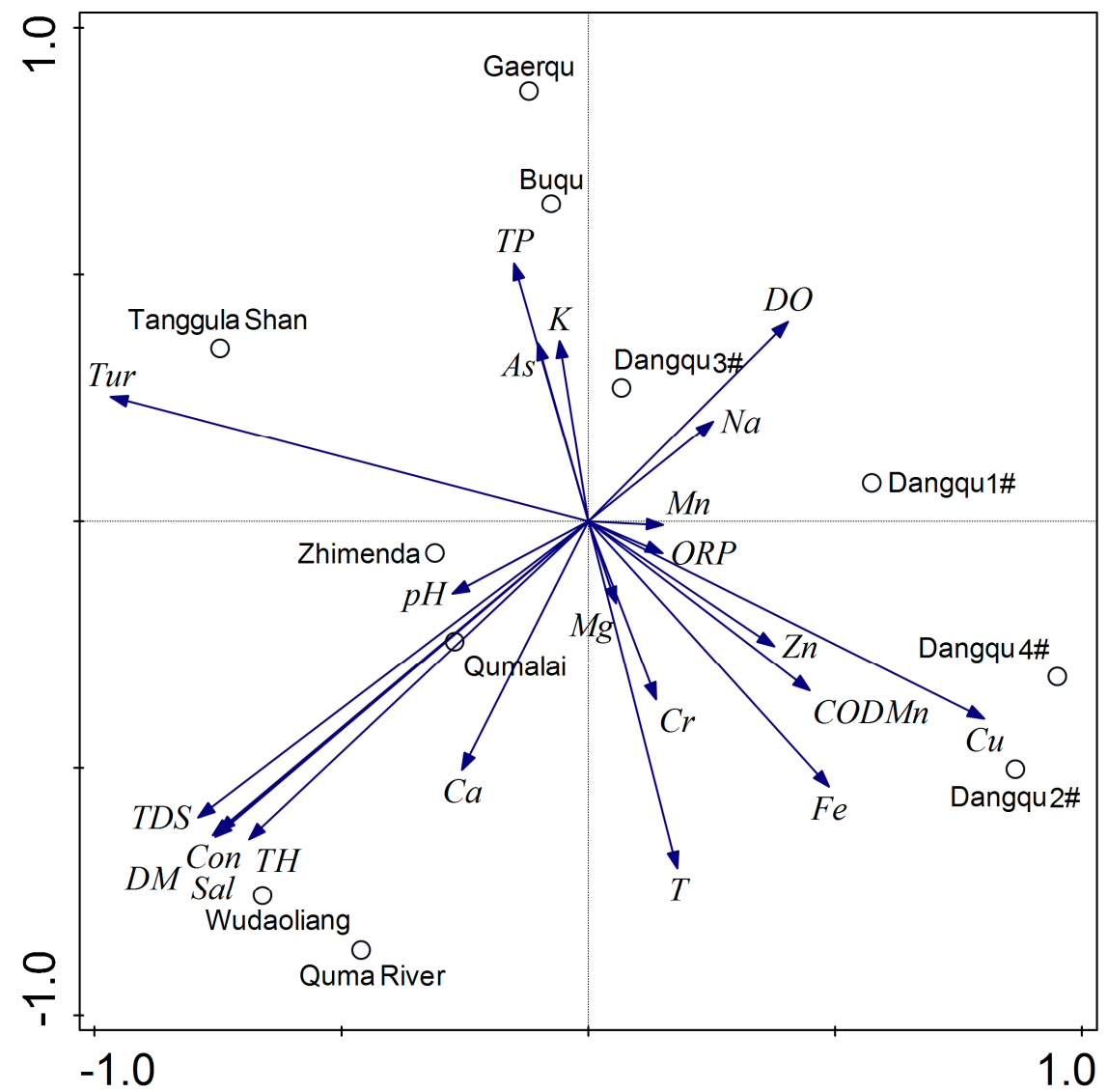

Figure 7. PCA analysis of 22 environmental variables $(T=$ temperature, $C o n=$ conductivity, $T D S=$ total dissolved solid, Sal = salinity, $D O=$ dissolved oxygen, $O R P=$ oxidation reduction potential, Tur $=$ turbidity, $T P=$ total phosphorous, $T H=$ total hardness, $D M=$ the degree of mineralization). 


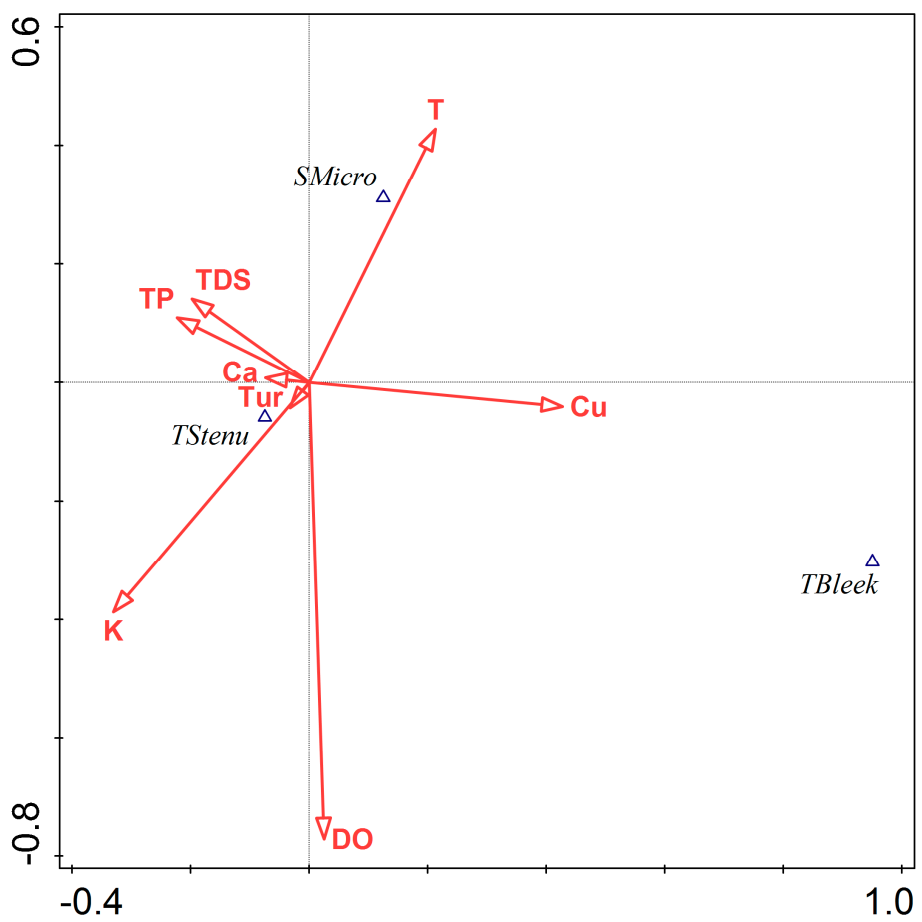

Figure 8. CCA analysis between fish and environmental factors (DO = dissolved oxygen, $\mathrm{T}=$ temperature, $\mathrm{TDS}=$ total dissolved solid, $\mathrm{TP}=$ total phosphorous, $\mathrm{Tur}=$ turbidity, $\mathrm{K}=$ potassium ion, $\mathrm{Ca}=$ calcium ion, $\mathrm{Cu}=$ copper ion, TStenu $=$ Triplophysa stenura, SMicro = Schizopygopsis microcephalus Herzenstein, TBleek = Triplophysa bleekeri).

\section{Discussion}

The Yangtze is the mother river of the Chinese nation, and its water quality is an essential issue for the local people in the basin regions [38]. The SRYR is the original place of the hydrological cycle throughout the Yangtze River Basin, and the changes of water environment in the SRYR will have an impact on the aquatic ecological environment and the sustainable water resources use of the whole Yangtze River Basin [4]. Therefore, it is crucial to illuminate the current status and change trends of the river water environment in the SRYR.

In past decades, a few studies have been conducted on the characteristics of river water environment and water quality in the SRYR. Fu et al. (1998) indicated that the physical and chemical characteristics of the water environment in the SRYR were basically kept within the original natural state and background value of the river water environment [39]. Water quality monitoring and assessment for surface water of the SRYR were conducted in 2008; the results showed that all water quality indicators (including $\mathrm{COD}, \mathrm{BOD}_{5}, \mathrm{NH}_{4}-\mathrm{N}$, fluoride, sulfide, $\mathrm{TN}, \mathrm{Cr}^{6+}$, phenol, $\mathrm{Hg}$, petroleum.etc) were in the range of class I according to the classification of GB3838-2002 in China, which indicated that no water contamination was found in the source area of the SRYR [40]. Water Spatial-temporal distribution of water quality indexes such as organic and metal pollutants in the SRYR in 2012, 2014 and 2015 demonstrated that most of the river water quality parameters in the SRYR were in the range of class I to class II, based on the guideline of GB3838-2002, and that organic pollutants such as phthalic acid esters were detected in surface water samples of the source area [10]. In the present research, classification of class I-II was observed in the majority of water quality indexes in rivers of the SRYR, and especially, the concentrations of TN in most sampling rivers were below the detectable limit, which indicates that nitrogen levels were low in this area, and much lower than in the midstream and downstream areas of the Yangtze River; this further suggests there is almost no effect from human activities. In general, the river water in the SRYR is basically in a natural state. However, the environmental problems caused by soil erosion, alpine wetland degradation, river-related project construction, domestic garbage 
produced by local herders and tourists, overgrazing, livestock manure, etc. cannot be ignored, as these affect the water ecological environment of the SRYR $[29,40]$. Therefore, the environmental protection of river water in the SRYR should be strengthened.

Water chemistry and dissolved materials in river water are strongly influenced by the lithological composition of the bed rock, hydro-climatic conditions, human activities and the ground water within the river basin $[38,41]$. Obvious zoning features were exhibited in the river hydrochemistry of the SRYR; the degree of mineralization ranged from 550 to $3100 \mathrm{mg} / \mathrm{L}$ in 2010, in which the northern rivers the Chumaer River belonged to the water chemical belt with strong degree of mineralization, the chemical belt with middle-strongly mineralized water appeared in the the western rivers Tuotuo River and Dangqu River referred to southern river exerted the lowest mineralized water [13]. Three types of hydrochemical characteristics were exhibited in the present research on the basis of regional differentiation and river differences in the SRYR [11]. The northern rivers refer to Chumer river (Wudaoliang and Quma River), which is lies to the north of Tongtian river. Compared with Dangqu River and Tuotuo River, the Chumer River had the highest conductivity, TDS and salinity in river water among all sampling rivers $(p<0.01)$, i.e., approximately twice than those of the Tuotuo River $(p<0.01)$ and about 10 times those of the Dangqu River $(p<0.01)$. However, the sediment concentration of the Chumaer River was relatively low, and the turbidity of the water was less than $20 \%$ that of the Tuotuo River $(p<0.01)$. The western rivers, Tuotuo river (Tanggula Shan), which is lies to the west of Tongtian river, showed a TDS greater than $1000 \mathrm{mg} / \mathrm{L}$ and high salinity, which is 4-8 times that of the Dangqu River and tributary rivers $(p<0.01)$. High salinity is caused by concentration through evaporation, which accelerates the accumulation of salt [11]. Tuotuo river has the highest sediment concentration among all the sampled rivers $(p<0.01)$. Its turbidity is approximately $4-11$ times that of the Chumaer River, and even thousands of times that of the Dangqu river $(p<0.01)$, which can be explained by the river sediment discharge in SRYR [42]. The sediment transport volume was the largest in the Tuotuo river, followed by the Chumaer river, and was the smallest in the Dangqu river. As for the southern rivers, the Dangqu and its tributaries (Gaerqu and Buqu), had less TDS than the northern rivers. The salinity of these rivers was relatively lower because glacier melt water is an important supply source for these rivers. As for metal ions, the water chemical constitution of the SRYR also showed a higher concentration of dissolved solutes, including $\mathrm{Ca}^{2+}$ and $\mathrm{Mg}^{2+}$. The value is not only higher than the average for water in Europe, Africa, and North and South America, but also higher than the Asian average, i.e., 1-2 times than in the waters of world rivers [43]. Those characteristics of river hydrochemistry in the SRYR are closely related to the natural geographical conditions of the region, which mainly depend on the lithology, flow process, water quantity and climatic conditions of the bedrock through which the river flows.

In recent years, much research regarding river aquatic organisms in the SRYR has been conducted, including field investigations of the compositions and community diversity of macrobenthos and phytoplankton in rivers $[9,12]$. However, there is a lack of data or research on the distribution of river fish and its relationship with environmental factors in the rivers of the SRYR. Habitat environment is an essential component of the river ecosystem [44]. Environmental factors, including water quality indicators, hydrological regime and river topographical features, have a significant influence for fish habitat distribution. Water quality indicators such as water temperature, dissolved oxygen, $\mathrm{pH}$ and sediment concentration are strongly associated with the growth and reproduction of fish. River flow, flow rate and water depth are the most basic hydrohydraulic parameters, and changes of these variable are closely related to fish habitats and river ecology [40,42]. There is a significant difference in the frequency distribution of the flow rate in the spawning area of the fish and the non-oviposition area [45]. The fish spawning and growth and reproduction of the juveniles are selective for the flow rate [46]. The water depth provides sufficient activity space for the fish and a proper hatching environment for the eggs. River topographical features have an impact on fish community function and structure [44]. Rivers with greater wide-depth ratios possess broad river valleys and well-developed river wash land, thus providing a more diverse habitat for fish [43]. Micro-habitat refers to the habitat environment 
such as gravel, sandy mud on the pebbles and plant litters, which also play an important role in fish distribution [47]. The river geomorphic unit and its characteristics, such as the density of the deep shoal and the type of sediment in the geomorphic unit, are also important factors for the survival of juveniles. The species richness, integrity and biomass of fish in the river with high sinuosity are higher than those in straight river sections [48]. The deep pool can provide a relatively calm rest environment for fish; shallows can meet the hydraulic environment required for fish to lay eggs, while the deep stream shoal interlaced with complex water flow can improve the success rate of fertilization [44,47].

In the present field investigation, the established relationship between the larval and juvenile fish distribution and water quality parameters indicated that the distribution of S. microcephalus exhibited a positive response to water temperature, the distribution of $T$. stenura had a positive response to $\mathrm{K}$, and a negative correlation with water temperature, T. bleekeri's distribution had a positive response to $\mathrm{Cu}$, while negative to TP and TDS. In addition, positive and negative relationships were observed in the larval and juvenile fish number with $\mathrm{pH}(r=0.57, p<0.05)$, turbidity $(r=0.68, p<0.01)$, water temperature $(r=-0.64, p<0.05)$ and ORP $(r=-0.69, p<0.01)$. The above results further demonstrated environmental factors, e.g., that water quality indicators had significant influence on the fish habitat distribution. In addition, large numbers of larval and juvenile fish were distributed in the Dangqu (Dangqu 1\#, Dangqu 2\# and Dangqu 3\#), Gaerqu, Tuotuo (Tanggula Shan) and Chumaer(Wudaoliang) rivers, which are mainly related to the habitat characteristics of juvenile fish. In the Dangqu river, the habitats of the main fish areas are characterized by curved river regimes, low flow rates, river banks with low sediment content or near-shore areas with large pebbles. The sampling section of Tuotuo River is a shallow shoal with a curved river regime, the flow rate is relatively slow, the sediment is mud, and the juveniles are distributed in a concentrated manner. The rivers of the Gaerqu River are curved to form a small river bay. The water in the beach has a high sediment content, and the riverbed is mixed with a large number of large pebbles and small gravel. In contrast, the juvenile fish are rarely collected in the near-shore area of the river section, such as the Tongtian River section, where no large pebbles exist and a steep river regime exists, in addition to a high flow rate and sediment concentration. Although the preliminary qualitative description and analysis of habitat factors such as flow rate, river bed matrix and river regime in three main rivers of the SRYR associated with the larvae and juvenile fish distributions based on field observations were carried out in present research, the key characteristics of ecological and hydrological elements including hydrological regime and river topographical features, which could affect the distributions of the larvae and juvenile fish, still could not be quantitatively illuminated by means of such a limited analysis. Further research is needed to establish a clear correlation between larvae and juvenile fish distributions and specific parameters of the hydrological regime and river topographical features via long-term field observations, aiming to provide a scientific basis for the management and protection of juvenile fish in the SRYR.

\section{Conclusions}

The water quality of river water in the SRYR was generally good in 2018, and the majority of water quality parameters, such as nitrogen, phosphorus, $\mathrm{COD}_{\mathrm{Mn}}$ and heavy metals, etc. in different rivers of the SRYR were in the range of classes I-II, based on Chinese surface water standards (GB3838-2002). The concentrations of four major ions occurred in the following order: $\mathrm{Ca}>\mathrm{Na}$ $>\mathrm{Mg}>\mathrm{K}$. Three species of larval and juvenile fish (Triplophysa stenura (T. stenura), Schizopygopsis microcephalus Steindachner (S. microcephalus) and Triplophysa bleekeri (T. bleekeri)) were distributed in the rivers of the SRYR, with T. stenura covering the widest distribution range and being the most abundant. The distributions of larval and juvenile fish species exhibited different relationships with the river water quality parameters.

Author Contributions: Conceptualization, L.Z.; methodology, X.T., L.L. and W.L.; investigation L.Z., W.L., W.G., W.Z. and D.G.; resources, Q.L. and P.X.; L.Z. wrote the manuscript and all authors contributed to improving the paper. 
Funding: This work was financially supported by National Key R\&D Program of China (Grant No.2018YFC0407603), Central Public-interest Scientific Institution Basal Research Fund (Grant No.CKSF2019292/SH, CKSF2017062/SH) and Outstanding Young Talents of National High-level personnel of special support program(CKSD2019542/SH).

Acknowledgments: We thank the reviewers for their useful comments and suggestions.

Conflicts of Interest: The authors declare no conflict of interest.

\section{Appendix A}

The relationship among the various water quality parameters and fish numbers is presented in Table A1, analyzed by Pearson correlations. 
Table A1. Pearson correlations of fish and environmental factors in rivers.

\begin{tabular}{|c|c|c|c|c|c|c|c|c|c|c|c|c|c|c|c|c|c|c|c|c|c|c|c|}
\hline & $\begin{array}{c}\text { Water } \\
\text { Temperature }\end{array}$ & Conductivity & TDS & Salinity & Do & $\mathrm{pH}$ & ORP & Turbidity & TP & $\operatorname{COD}_{M n}$ & $\begin{array}{c}\text { Degree of } \\
\text { Mineralization }\end{array}$ & $\begin{array}{c}\text { Total } \\
\text { Hardness }\end{array}$ & K & $\mathrm{Na}$ & $\mathrm{Ca}$ & $\mathrm{Mg}$ & $\mathrm{Fe}$ & Mn & $\mathrm{Cu}$ & $\mathrm{Zn}$ & $\mathrm{Cr}$ & As & $\begin{array}{c}\text { Fish } \\
\text { Number }\end{array}$ \\
\hline \multicolumn{24}{|l|}{$\begin{array}{c}\text { Water } \\
\text { temperature }\end{array}$} \\
\hline Conductivity & 0.31 & & & & & & & & & & & & & & & & & & & & & & \\
\hline TDS & 0.23 & $0.99 * *$ & & & & & & & & & & & & & & & & & & & & & \\
\hline Salinity & 0.22 & $0.99^{* *}$ & $\underset{* *}{1.00}$ & & & & & & & & & & & & & & & & & & & & \\
\hline DO & -0.39 & -0.55 * & -0.50 & -0.50 & & & & & & & & & & & & & & & & & & & \\
\hline $\mathrm{pH}$ & -0.45 & 0.35 & 0.40 & 0.41 & -0.02 & & & & & & & & & & & & & & & & & & \\
\hline ORP & 0.53 * & -0.15 & -0.22 & -0.23 & -0.37 & -0.62 & & & & & & & & & & & & & & & & & \\
\hline Turbidity & -0.41 & 0.27 & 0.32 & 0.31 & -0.10 & $\underset{* * *}{0.75}$ & -0.36 & & & & & & & & & & & & & & & & \\
\hline TP & -0.41 & $\begin{array}{l}-0.24 \\
-0.17\end{array}$ & $\begin{array}{l}-0.23 \\
-0.17\end{array}$ & $\begin{array}{l}-0.22 \\
-0.18\end{array}$ & $\begin{array}{c}0.02 \\
0.53 *\end{array}$ & $\begin{array}{c}-0.12 \\
0.16\end{array}$ & -0.07 & $\begin{array}{l}-0.06 \\
-0.10\end{array}$ & -0.34 & & & & & & & & & & & & & & \\
\hline $\begin{array}{l}\text { Degree of } \\
\text { mineralization }\end{array}$ & 0.23 & $0.99 * *$ & 0.99 & 0.99 & -0.53 & 0.43 & -0.24 & 0.31 & -0.17 & -0.14 & & & & & & & & & & & & & \\
\hline Total hardness & 0.40 & 0.95 ** & 0.93 & 0.93 & -0.62 & 0.34 & -0.13 & 0.28 & -0.16 & -0.09 & $0.95 * *$ & & & & & & & & & & & & \\
\hline $\begin{array}{c}\mathrm{K} \\
\mathrm{Na}\end{array}$ & $\begin{array}{l}-0.38 \\
-0.20\end{array}$ & $\begin{array}{l}-0.23 \\
-0.19\end{array}$ & $\begin{array}{l}-0.21 \\
-0.15\end{array}$ & $\begin{array}{l}-0.20 \\
-0.16\end{array}$ & $\begin{array}{c}-0.18 \\
0.19\end{array}$ & $\begin{array}{c}-0.17 \\
0.49\end{array}$ & $\begin{array}{l}-0.04 \\
-0.05\end{array}$ & $\begin{array}{l}-0.01 \\
0.69 * *\end{array}$ & $\begin{array}{l}-0.05 \\
-0.20\end{array}$ & $\begin{array}{c}-0.47 \\
0.38\end{array}$ & $\begin{array}{l}-0.24 \\
-0.12\end{array}$ & $\begin{array}{l}-0.27 \\
-0.13\end{array}$ & -0.21 & & & & & & & & & & \\
\hline $\mathrm{Ca}$ & $\begin{array}{l}-0.0 \\
0.27\end{array}$ & $0.64^{*}$ & 0.65 * & $0.66^{*}$ & $\begin{array}{l}0.19 \\
-0.28\end{array}$ & 0.00 & $\begin{array}{l}-0.05 \\
-0.11\end{array}$ & -0.18 & $\begin{array}{c}-0.13 \\
0.13\end{array}$ & $\begin{array}{l}0.00 \\
-0.03\end{array}$ & $0.69^{* *}$ & $0.63^{*}$ & $\begin{array}{l}-0.21 \\
-0.21\end{array}$ & -0.28 & & & & & & & & & \\
\hline $\mathrm{Mg}$ & -0.06 & -0.02 & -0.02 & -0.01 & -0.43 & -0.03 & -0.03 & -0.04 & -0.33 & -0.32 & -0.03 & 0.00 & 0.87 & -0.20 & -0.14 & & & & & & & & \\
\hline $\mathrm{Fe}$ & 0.14 & -0.01 & -0.01 & 0.00 & 0.25 & 0.08 & 0.07 & -0.32 & -0.27 & 0.77 & 0.01 & -0.02 & -0.25 & 0.11 & 0.31 & -0.10 & & & & & & & \\
\hline $\mathrm{Mn}$ & -0.10 & -0.19 & -0.17 & -0.17 & 0.38 & -0.14 & -0.10 & -0.23 & 0.57 * & -0.08 & -0.18 & -0.25 & -0.50 & -0.28 & 0.06 & -0.69 & -0.14 & & & & & & \\
\hline $\begin{array}{l}\mathrm{Cu} \\
\mathrm{Zn}\end{array}$ & $\begin{array}{l}0.15 \\
0.21\end{array}$ & $\begin{array}{l}-0.29 \\
-0.12\end{array}$ & $\begin{array}{l}-0.28 \\
-0.14\end{array}$ & $\begin{array}{l}-0.28 \\
-0.14\end{array}$ & $\begin{array}{c}0.27 \\
-0.28\end{array}$ & $\begin{array}{l}0.19 \\
0.19\end{array}$ & $\begin{array}{c}-0.08 \\
0.05\end{array}$ & $\begin{array}{l}-0.28 \\
-0.09\end{array}$ & $\begin{array}{l}-0.40 \\
-0.30\end{array}$ & $\begin{array}{c}0.62 \\
-0.14\end{array}$ & $\begin{array}{l}-0.26 \\
-0.14\end{array}$ & $\begin{array}{l}-0.28 \\
-0.10\end{array}$ & $\begin{array}{c}-0.18 \\
0.05\end{array}$ & $\begin{array}{c}0.18 \\
-0.05\end{array}$ & $\begin{array}{l}-0.09 \\
-0.32\end{array}$ & $\begin{array}{l}0.09 \\
0.36\end{array}$ & $\begin{array}{l}0.66 \text { * } \\
-0.12\end{array}$ & 0.00 & $057^{*}$ & & & & \\
\hline $\mathrm{Cr}$ & 0.28 & 0.13 & 0.10 & 0.10 & $\begin{array}{l}-0.20 \\
-0.07\end{array}$ & $\begin{array}{l}0.19 \\
-0.08\end{array}$ & 0.32 & $\begin{array}{l}-0.09 \\
-0.21\end{array}$ & 0.01 & 0.50 * & $\begin{array}{l}-0.14 \\
0.12\end{array}$ & 0.21 & -0.21 & 0.00 & $\begin{array}{l}-0.52 \\
0.40\end{array}$ & $\begin{array}{l}0.00 \\
-0.13\end{array}$ & 0.76 & $\begin{array}{l}0.00 \\
-0.09\end{array}$ & 0.27 & -0.28 & & & \\
\hline As & -0.15 & -0.19 & -0.15 & -0.16 & -0.10 & 0.22 & -0.07 & $0.64 *$ & -0.02 & -0.24 & -0.16 & -0.15 & 0.20 & $0.60 *$ & -0.35 & 0.15 & -0.49 & -0.08 & -0.09 & 0.20 & -0.35 & & \\
\hline Fish number & $-0.64 *$ & 0.23 & 0.31 & 0.31 & 0.11 & 0.57 * & -0.69 & $0.68 * *$ & 0.39 & -0.29 & 0.33 & 0.20 & -0.01 & 0.26 & 0.07 & -0.20 & -0.47 & 0.17 & -0.48 & -0.32 & -0.49 & 0.36 & \\
\hline
\end{tabular}

** Correlation is significant at the 0.01 level. * Correlation is significant at the 0.05 level. 


\section{References}

1. Qi, W.; Müller, B.; Pernet-Coudrier, B.; Singer, H.; Liu, H.; Qu, J.; Berg, M. Organic micropollutants in the Yangtze River: Seasonal occurrence and annual loads. Sci. Total Environ. 2014, 472, 789-799. [CrossRef] [PubMed]

2. Tilman, F.; Xiao, H.; Björn, S.; Wu, L.; Hou, J.; Yin, D.; Zhang, X.; Ji, R.; Yuan, X.M.; Roß, N.; et al. Solution by dilution? A review on the pollution status of the Yangtze River. Environ. Sci. Pollut. Res. 2013, 20, 6934-6971.

3. Qi, D.; Zhang, S.; Li, Y.Q. Research progress on variations of the climate and water resources in the Source Region of the Yangtze River. Plateau Mt. Meteor. Res. 2013, 33, 89-96.

4. Chai, Y.B.; Zhao, W.H.; Guo, W.J. Water Environment Capacity and Limit Discharge of Pollutants in Tongtian River Basin and the Source Region of Yangtze River. J. Yangtze River Sci. Res. Inst. 2016, 33, 6-11.

5. Li, Z.J.; Li, Z.X.; Song, L.L.; Ma, J.Z.; Song, Y. Environment significance and hydrochemical characteristics of supra-permafrost water in the source region of the Yangtze River. Sci. Total Environ. 2018, 644, 1141-1151.

6. Shen, Y.P.; Wang, G.Y.; Wang, G.X.; Pu, J.C.; Wang, X. Impacts of climate change on glacial water resources and hydrological cycles in the Yangtze River source region, the Qinghai-Tibetan Plateau, China: A Progress Report. Sci. Cold Arid Reg. 2009, 1, 3-23.

7. Guo, X.L. Review and reflections on CRSRI's scientific investigation in the Source Area of Yangtze River and Lancang River. J. Yangtze River Sci. Res. Inst. 2012, 29, 1-5.

8. Liang, E.; Shao, X.; Qin, N. Tree-ring based summer temperature reconstruction for the source region of the Yangtze River on the Tibetan Plateau. Glob. Planet. Chang. 2008, 61, 313-320. [CrossRef]

9. Yin, D.; Xu, J.; Yan, J.; Zhen, X.U. Characteristics of phytoplankton assemblage and distribution in the Source Regions of the Yangtze River and Lancang River. J. Yangtze River Sci. Res. Inst. 2017, 34, 61-66.

10. Huang, Z.; Liu, Y.; Zhao, W.; Zhao, L. Discussion on recent spatial-temporal distribution of water quality in Changjiang River Source area. J. Yangtze River Sci. Res. Inst. 2016, 33, 46-50.

11. Jiang, L.; Yao, Z.; Liu, Z.; Rui, W.; Wu, S. Hydrochemistry and its controlling factors of rivers in the source region of the Yangtze River on the Tibetan Plateau. J. Geochem. Explor. 2015, 155, 76-83. [CrossRef]

12. Pan, B.; Wang, Z.; Li, Z.; Yu, G.; Xu, M.; Na, Z.; Brierley, G. An exploratory analysis of benthic macroinvertebrates as indicators of the ecological status of the Upper Yellow and Yangtze Rivers. J. Geogr. Sci. 2013, 23, 871-882. [CrossRef]

13. Zhuo, H.; Liu, Y.; Zheng, H.; Wu, Y. Investigation and analysis on water environment of sources area of Yangtze River. Yangtze River 2012, 43, 23-26.

14. Bian, H.; Lü, H.; Sadeghi, A.; Zhu, Y.; Yu, Z.; Ou, F.; Su, J.; Chen, R. Assessment on the Effect of Climate Change on Streamflow in the Source Region of the Yangtze River, China. Water 2017, 9, 70. [CrossRef]

15. Hu, G.; Lu, J.; Yan, C. Driving forces responsible for aeolian desertification in the source region of the Yangtze River from 1975 to 2005. Environ. Earth Sci. 2012, 66, 257-263. [CrossRef]

16. Hayashi, S.; Murakami, S.; Xu, K.; Watanabe, M. Simulation of the reduction of runoff and sediment load resulting from the Gain for Green Program in the Jialingjiang catchment, upper region of the Yangtze River, China. J. Environ. Manag. 2015, 149, 126-137. [CrossRef] [PubMed]

17. Yu, G.; Brierley, G.; He, Q.; Wang, Z.; Blue, B.; Ma, Y. An environmental gradient of vegetative controls upon channel planform in the source region of the Yangtze and Yellow Rivers. Catena 2014, 119, 143-153. [CrossRef]

18. China, State Environmental Protection Administration. Environmental Quality Standard for Surface Water (GB3838-2002); China Environmental Science Press: Beijing, China, 2002.

19. China, State Environmental Protection Administration. Monitoring and Analytical Method of Water and Wastewater, 4th ed.; China Environmental Science Press: Beijing, China, 2002.

20. Wu, Y.; Wu, C. Fishes of Qinghai-Tibet Plateau; Sichuan Publishing House of Science \& Technology: Chengdu, China, 1992.

21. Roy, S.; Gaillardet, J.; Allègre, C.J. Geochemistry of dissolved and suspended loads of the Seine River, France: Anthropogenic impact, carbonate and silicate weathering. Geochim. Cosmochim. Acta 1999, 63, 1277-1292. [CrossRef]

22. Lewis, W.M.; Wurtsbaugh, W.A.; Paerl, H.W. Rationale for control of anthropogenic nitrogen and phosphorus to reduce eutrophication of inland waters. Environ. Sci. Technol. 2011, 45, 10300-10305. [CrossRef] [PubMed] 
23. Zhao, J.; Zhang, W.; Sun, M.J.; Wei, X.S. Optimization of the spectrophotometry analysis conditions of the permanganate index. Adv. Mater. Res. 2013, 610-613, 1103-1108. [CrossRef]

24. Raju, N.J.; Shukla, U.K.; Ram, P. Hydrogeochemistry for the assessment of groundwater quality in Varanasi: A fast-urbanizing center in Uttar Pradesh, India. Environ. Monit. Assess. 2011, 173, 279-300. [CrossRef] [PubMed]

25. Zhou, C.J.; Dong, S.C.; Guo, W. Resources characteristics of the major rivers in the source areas of the Changjiang, Huanghe and Lancangjiang. J. Nat. Resour. 2011, 16, 493-498.

26. Meybeck, M. Global Chemical weathering of surficial rocks estimated from river dissolved loads. Am. J. Sci. 1987, 287, 401-428. [CrossRef]

27. Hai, X.; Hou, Z.; An, Z.; Liu, X.; Dong, J. Major ion chemistry of waters in Lake Qinghai catchments, NE Qinghai-Tibet plateau, China. Quat. Int. 2010, 212, 35-43.

28. Ahmad, T.; Khanna, P.P.; Chakrapani, G.J.; Balakrishnan, S. Geochemical characteristics of water and sediment of the Indus river, Trans-Himalaya, India: Constraints on weathering and erosion. J. Asian Earth Sci. 1998, 16, 333-346. [CrossRef]

29. Fu, D.Q. The Investigate and Analysis about background value of water environmental in the Soure Area of Yangtze River. Environ. Monit. Chin. 1998, 14, 9-11.

30. Dalzochio, T.; Gzp, R.; Lar, S.; De Souza, M.S.; Petry, I.E.; Andriguetti, N.B.; Gjh, S.; Da, S.L.; Gehlen, G. In situ monitoring of the Sinos River, southern Brazil: Water quality parameters, biomarkers, and metal bioaccumulation in fish. Environ. Sci. Pollut. Res. 2018, 25, 9485-9500. [CrossRef]

31. Rashleigh, B.; Cyterski, M.; Smith, L.M.; Nestlerode, J.A. Relation of fish and shellfish distributions to habitat and water quality in the Mobile Bay estuary, USA. Environ. Monit. Assess. 2009, 150, 181-192. [CrossRef]

32. Jeppesen, E.; Pekcan-Hekim, Z.; Lauridsen, T.L.; Søndergaard, M.; Jensen, J.P. Habitat distribution of fish in late summer: Changes along a nutrient gradient in Danish lakes. Ecol. Freshw. Fish. 2010, 15, 180-190. [CrossRef]

33. Wang, G.; Wang, Y.; Li, Y.; Cheng, H. Influences of alpine ecosystem responses to climatic change on soil properties on the Qinghai-Tibet Plateau, China. Catena 2007, 70, 506-514. [CrossRef]

34. Song, F.; Tang, M.; Wang, D. New evidence for the Qinghai-Xizang (Tibet) Plateau as a pilot region of climatic fluctuation in China. Chin. Sci. Bull. 1998, 43, 1745-1749.

35. Wang, H.; Ma, M.; Geng, L. Monitoring the recent trend of aeolian desertification using Landsat TM and Landsat 8 imagery on the north-east Qinghai-Tibet Plateau in the Qinghai Lake basin. Nat. Hazards 2015, 79, 1753-1772. [CrossRef]

36. Ming, X.; Shan, Z.; Tong, J. Response of river water temperature to climate change in source regions of Yangtze River. Yangtze River 2018, 49, 48-54.

37. Tao, J.; He, D.; Kennard, M.J.; Ding, C.; Bunn, S.E.; Liu, C.; Jia, Y.; Che, R.; Chen, Y. Strong evidence for changing fish reproductive phenology under climate warming on the Tibetan Plateau. Glob. Chang. Biol. 2018, 24, 2093-2104. [CrossRef] [PubMed]

38. Qu, B.; Sillanpää, M.; Zhang, Y.; Guo, J.; Wahed, M.S.M.A.; Kang, S. Water chemistry of the headwaters of the Yangtze River. Environ. Earth Sci. 2015, 74, 6443-6458. [CrossRef]

39. Fu, D.; Fu, Q.; Shu, J. The analysis about physical and chemical characteristic of water environmental in the Source Area of Yangzte River. Environ. Monit. Chin. 1998, 14, 2-4.

40. Lu, S.; Shi, H.X.; Li, P. Environmental assessment for water of Yangtze River of Source Area of Lancang, Yellow and Yangtze River. J. Environ. Health 2009, 26, 604-605.

41. Stallard, R.F.; Edmond, J.M. Geochemistry of the Amazon 2. The influence of geology and weathering environment on the dissolved load. J. Geophys. Res. Ocean. 1983, 88, 9671-9688. [CrossRef]

42. Yan, X.; Zhou, Y.J.; Yao, S.M. Valley landscape and characteristics of flow and sediment of the rivers in Yangtze River Source area. J. Yangtze River Sci. Res. Inst. 2018. [CrossRef]

43. Xiang, H.; Sillanpää, M.; Gjessing, E.T.; Vogt, R.D. Water quality in the Tibetan Plateau: Major ions and trace elements in the headwaters of four major Asian rivers. Sci. Total Environ. 2009, 407, 6242-6254.

44. Ma, L.; Bao, Y.; Gao, L.; Xu, F.; Deng, H.; Shang, X. Primary study on environmental assessment index system of fish habitat. Water Resour. Hydropower Eng. 2017, 48, 77-81.

45. Sempeski, P.; Gaudin, P. Habitat selection by grayling-I. Spawning habitats. J. Fish. Biol. 2010, 47, $256-265$.

46. Sempeski, P.; Gaudin, P. Habitat selection by grayling-II. Preliminary results on larval and juvenile daytime habitats. J. Fish. Biol. 2010, 47, 345-349. 
47. Chen, K.; Tao, J. Research on eco-hydrology of river habitat. Water Resour. Prot. 2015, 31, 52-56.

48. Rhoads, B.L.; Schwartz, J.S.; Porter, S. Stream geomorphology, bank vegetation, and three-dimensional habitat hydraulics for fish in midwestern agricultural streams. Water Resour. Res. 2003, 39, 2-13. [CrossRef]

(C) 2019 by the authors. Licensee MDPI, Basel, Switzerland. This article is an open access article distributed under the terms and conditions of the Creative Commons Attribution (CC BY) license (http://creativecommons.org/licenses/by/4.0/). 